\title{
Ants from Thessaly, Greece (Hymenoptera: Formicidae)
}

\author{
LECH BorOWIEC ${ }^{*}$, SEBASTIAN SALATA \\ Department of Biodiversity and Evolutionary Taxonomy, University of Wrocław, \\ Przybyszewskiego 65, 51-148 Wrocław, Poland
}

\begin{abstract}
A complete list of 107 ant species (including morphospecies not attributed to any known taxon) recorded from Thessaly, Greece, is presented. New records from 40 sampling localities explored during two field trips in 2012 and 2017, and also from literature data are included. Temnothorax sordidulus (MÜLLER, 1923) and Temnothorax tauricus (RUZSKY, 1902) are new to Greece; 38 species were recorded from Thessaly for the first time.
\end{abstract}

KEY WORDS: ants, faunistics, Greece, Thessaly, new national records, new regional records.

\section{INTRODUCTION}

The ant fauna of Greece has been intensively studied in recent years. The checklist of Greek ants published by LEGAKIS (2011) can be regarded as the inspiration for further, more detailed studies. Despite a number of errors, this checklist has become the basis for further regional surveys. Other recent papers, including checklists for several Greek regions and taxonomic revisions, have enabled gaps in the knowledge of this country's ant biodiversity to be filled (BOER 2013, BOROWIEC \& SALATA 2012, 2013, 2014a, 2014b, 2017a, 2017b, 2018, BRAČKO et al. 2016, CsŐsZ et al. 2015, SALATA \& BOROWIEC 2015a, 2015b, 2015c, 2016, 2017). These papers record at least 280 species from Greece and suggest that there are more than 20 species new to science. This ranks the Greek ant fauna as the richest in Europe. Based on the literature mentioned above and our unpublished data, the following numbers of ant species have been recorded from the various geographical

\footnotetext{
*Corresponding author: lech.borowiec@uwr.edu.pl
} 
regions: Macedonia (158), the Peloponnese (129), Thrace (116), the Dodecanese (111), the Ionian Islands (107), the North Aegean Islands (106), Crete (100), Sterea Ellas (89), Epirus (89), Thessaly (72) and the Cyclades (46). These results show that Thessaly remains the least-known, large continental province of Greece in this respect.

One of the geographical and historical regions of Greece, Thessaly is situated centrally in the Greek mainland and is bordered by Macedonia to the north, Epirus to the west, Sterea Ellas to the south and the Aegean Sea to the east. Thessaly has also retained its position and borders within the new administrative division of Greece. Thessaly is divided into five regional units and covers an area of some 14037 square kilometres. Karditsa, together with a large part of the Larissa and Trikala units are primarily agricultural areas. The Northern Sporades consist of 24 small islands, only four of which are permanently inhabited. Magnesia and parts of the Trikala and Larissa units are mountainous, including part of the highest mountain massif in Greece - Mt. Olympus (2917 m), the Pindus range (2637 m), Mt. Ossa (1978 m) and Mt. Pelion (1624 m). Our collecting sites were situated mostly in the mountainous areas of eastern Thessaly, but some samples were also collected in agricultural areas, lowland pastures and forests.

\section{MATERIALS AND METHODS}

We sampled ants in summer 2012 and in spring 2017. The main method, applied at all sites, was direct sampling (collecting by hand). Ant nests and individual specimens were collected on the ground, in leaf litter, under stones, in dead wood, on tree trunks and twigs. This method was occasionally supplemented by litter sifting. All specimens were preserved in $75 \%$ pure ethanol.

All the sampled localities are listed below with their geographical coordinates and notes on the habitats. The numbers of the localities refer to the locality code in the coding system used in the Database and Collection of Greek Ants housed at the University of Wrocław. The localities are arranged chronologically (except the last sample).

The images of the ant specimens in this paper were taken using Nikon SMZ 1500 and Nikon SMZ 18 stereomicroscopes, a Nikon D5200 camera and Helicon Focus software.

Below, we present a checklist of all the known ant species from Thessaly, based on our samples and literature data (BOROwIEC \& SALATA 2012, 2013, 2014a, 2017a, 2017b, 2017c, unpubl. data, BRAČKO et al. 2016, CsÖSZ et al. 2015). We also discuss the status and distribution range of poorly known or formally unnamed species. Data relating to 44 species new to Thessaly, collected during the first expedition in 2012, have already been published (BOROWIEC \& SALATA 2013), but we repeat them here to maintain consistency of the material from both expeditions. 
THE_047 - Larissa, Ossa Mts., Evaggelismos-Elatia road, altitude 117 m, 2012-09-06, $39.81762 \mathrm{~N} / 22.53357 \mathrm{E}$, pastures;

THE_048 - Larissa, Ossa Mts., Sikourio-Spilia road, 544 m, 2012-09-06, 39.77562 N/ $22.6106 \mathrm{E}$, pine forest;

THE_049 - Larissa, Ossa Mts., vicinity of Spilia, 822 m, 2012-09-06, 39.80038 N/ 22.64921 E, mountain pastures with shrubs;

THE_053 - Larissa, Ossa Mts., Omoli-Stomio road, loc. 1, 27 m, 2012-09-08, $39.88933 \mathrm{~N} / 22.66243 \mathrm{E}$, deciduous forest;

THE_054 - Larissa, Ossa Mts., Omoli-Stomio Rd. loc. 2, 84 m, 2012-09-08, 39.8708 N/ 22.69751 E, deciduous forest;

THE_055 - Larissa, Ossa Mts., Stomio-Karitsa road, 137 m, 2012-09-08, 39.85775 N/ 22.74714 E, deciduous forest;

THE_056 - Larissa, Ossa Mts., Ag. Dimitrios Mon. near Stomio, 162 m, 2012-09-08, $39.85903 \mathrm{~N} / 22.74025 \mathrm{E}$, deciduous forest around an old monastery;

THE_412 - Larissa, Kokkino Nero, 3 m, 2017-05-03, 39.83389 N / 22.79379 E, gardens in an urban area;

THE-412a - Larissa, Kokkio Nero, 3 m, 2017-05-07, 39.83389 N / 22.79379 E, roadsides in an urban area;

THE-412b - Larissa, Kokkino Nero, 3 m, 2017-05-10, 39.83389 N / 22.79379 E, stream valley in an urban area;

THE_413 - Larissa, 600 m SE of Karitsa, 300 m, 2017-05-04, 39.84009 N / 22.76983 E, deciduous forest;

THE_414 - Larissa, 1.3 km SE of Karitsa, 360 m, 2017-05-04, 39.83331 N / 22.77258 E, chestnut forest;

THE_415 - Larissa, $2.4 \mathrm{~km}$ SE of Karitsa, 425 m, 2017-05-04, 39.82632 N / 22.77557 $\mathrm{E}$, stream valley in a deciduous forest;

THE_416 - Larissa, 2.6 km SE of Karitsa, 360 m, 2017-05-04, 39.82348 N / 22.77843 E, deciduous forest;

THE_417 - Larissa, 1.9 km NW of Karitsa, 435 m, 2017-05-04, 39.84991 N / 22.74069 E, deciduous forest;

THE_418 - Larissa, near Gerakari, 120 m, 2017-05-05, 39.69498 N / 22.69295 E, dry pastures with shrubs and rocks;

THE_419 - Magnesia, $1 \mathrm{~km} \mathrm{SW}$ of Ano Kerasia, 580 m, 2017-05-05, 39.48063 N / $22.94874 \mathrm{E}$, light oak forest;

THE_420 - Magnesia, Ano Kerasia, 660 m, 2017-05-05, 39.48621 N / 22.95425 E, oak forest;

THE_421 - Magnesia, $2.5 \mathrm{~km}$ N of Kanalia, 520 m, 2017-05-05, 39.5226 N / 22.88144 E, pastures with oak shrubs; 
THE_422 - Magnesia, 3 km N of Kanalia, 555 m, 2017-05-05, 39.52494 N / 22.8887 E, pastures with large oaks;

THE_423 - Larissa, Karitsa-Mt. Ossa road, km 2.7, 510 m, 2017-05-06, 39,84991 N / $22,74069 \mathrm{E}$, beech forest;

THE_424 - Larissa, Karitsa-Mt. Ossa road, km3.5, 680 m, 2017-05-06, 39,84663 N / 22,7216 E, beech forest;

THE_425 - Larissa, Karitsa-Mt. Ossa road, km 6, 990 m, 2017-05-06, 39,83615 N / 22,69249 E, mixed forest;

THE_426 - Larissa, Mt. Ossa ski centre, 1520 m, 2017-05-06, 39,80844 N / 22,68604 $\mathrm{E}$, alpine pastures with rocks;

THE_427 - Larissa, Mt. Ossa N slope, 1165 m, 2017-05-06, 39,81722 N / 22,67628 E, fir forest;

THE_428 - Larissa, Karitsa-Mt. Ossa road, km 7, 1060 m, 2017-05-06, 39,83203 N / 22,68361 E, deciduous forest;

THE_429 - Magnesia, near Katochori, 500 m, 2017-05-07, 39.39402 N / 22.99603 E, stream with plane trees;

THE_430 - Magnesia, Mt. Pelion ski centre loc. 2, 1170 m, 2017-05-07, 39.39129 N / 23.08273 E, beech forest;

THE_431 - Magnesia, Mt. Pelion ski centre loc. 1, 1050 m, 2017-05-07, 39.39139 N / $23.10407 \mathrm{E}$, beech forest;

THE_432 - Magnesia, Mt. Pelion 3.4 km SE of Chania, 990 m, 2017-05-07, 39.38074 $\mathrm{N} / 23.02727 \mathrm{E}$, mountain pastures with shrubs and rocks;

THE_433 - Larissa, 6.4 km E of Agia, 60 m, 2017-05-07, 39.70066 N / 22.82744 E, dry roadsides with plane trees;

THE_436 - Larissa, Kato Olimbos Mts., Kalipefki, 1070 m, 2017-05-08, 39.97208 N / $22.47133 \mathrm{E}$, mountain pastures beside a coniferous forest;

THE_437 - Larissa, Kato Olimbos Mts., $1.1 \mathrm{~km} \mathrm{~N}$ of Kalipefki, 1150 m, 2017-05-08, 39.97782 N / 22.45529 E, fir + pine forest;

THE_438 - Larissa, Kato Olimbos Mts., 4.4 km S of Sikaminea, 1115 m, 2017-05-08, 39.92249 N / 22.36277 E, pine forest on rocks;

THE_439 - Larissa, Kato Olimbos Mts., $6.2 \mathrm{~km} \mathrm{~S}$ of Sikaminea, 760 m, 2017-05-08, 39.90736 N / 22.37109 E, pastures and stream with plane trees;

THE_440 - Larissa, Kato Olimbos Mts., $6.1 \mathrm{~km} \mathrm{~S}$ of Kalipefki, 855 m, 2017-05-09, $39.91322 \mathrm{~N} / 22.4641 \mathrm{E}$, mountain pastures;

THE_441 - Larissa, Mt. Olympus, EOCHO ski centre, 1720 m, 2017-05-09, 40.03592 $\mathrm{N} / 22.33387 \mathrm{E}$, alpine pastures;

THE_442 - Larissa, Mt. Olympus, $1.3 \mathrm{~km}$ W of EOCHO ski centre, $1560 \mathrm{~m}, 2017-05-$ 09, 40.03304 N / 22.31808 E, alpine pastures with shrubs; 
THE_443 - Larissa, Mt. Olympus, $2.8 \mathrm{~km}$ W of EOCHO ski centre, $1340 \mathrm{~m}, 2017-05$ $09,40.0255 \mathrm{~N} / 22.30421 \mathrm{E}$, alpine pastures with shrubs;

THE_444 - Larissa, Mt. Olympus, $5.3 \mathrm{~km}$ E of Olimpiada, $800 \mathrm{~m}$, 2017-05-09, $40.00989 \mathrm{~N} / 22.31096 \mathrm{E}$, stream valley with deciduous forest;

THE_445 - Trikala, Panagia near Koridallos, 925 m, 2017-04-07, 39.78958 N / 21.30867 E, Meteora historic site.

We recorded the distribution of the species listed here only in Greek provinces. General distribution data is available in a recent catalogue of European and Mediterranean ants (BOROWIEC 2014).

\section{LIST OF SPECIES}

(species new to Thessaly are marked with an asterisk)

\section{Acropyga paleartica MENOZZI, 1936}

Note: Recorded generally from Thessaly by LEGAKIS (2011), but without any bibliographic reference. Thus, the occurrence of $A$. paleartica in Thessaly needs confirmation based on recently collected material. Recorded from Crete, the Dodecanese, the Peloponnese and Sterea Ellas.

\section{Aphaenogaster epirotes (EMERY, 1895)*}

Localities: 419, 420, 421, 440 .

Note: Recorded from the East Aegean Is., the Ionian Is., Macedonia, the Peloponnese, Sterea Ellas and Thrace. New to Thessaly.

\section{Aphaenogaster subterranea (LATREILLE, 1798)*}

Localities: 054, 055, 056, 412b, 413, 414, 415, 417, 420, 422, 423, 424, 426, 429, 439, 444.

Note: Recorded from the Cyclades, the East Aegean Is., Epirus, the Ionian Is., Macedonia, Peloponnese, Sterea Ellas, Thessaly and Thrace. We classified all samples with a partly pale body and reduced microreticulation on the top of the head as A. subterranea. However, its conspecificity with the true A. subterranea is being studied. Molecular data suggest that populations of $A$. subterranea auct. from Europe represent two taxa, morphologically very similar but separated genetically and ecologically (C. GALKOWSKI letter inf.). Previously recorded from localities 054, 055, 056 by BOROWIEC \& SALATA (2012) 


\section{Aphaenogaster cf. subterranea $\mathrm{sp.} 2^{*}$}

Locality: 425 .

Note: Recorded from the Peloponnese, new to Thessaly. Our material from Greece shows that at least seven morphospecies belonging to the A. subterranea complex occur in this country. However, only two of them have a formal name, i.e. A. subterranea (LATREILle, 1798) and A. lesbica Forel, 1913. One of the undescribed morphospecies is characterized by the sculptured top of the head and occurs in the Peloponnese and Thessaly. The status and formal name of the samples from these provinces will be explained in the future, following the revision of all Greek taxa from the A. subterranea complex.

\section{Bothriomyrmex communistus SANTSCHI, 1919}

Localities: 047, 440.

Note: Recorded from the Dodecanese, the Eastern Aegean Is., Epirus, the Ionian Is., Macedonia, the Peloponnese, Sterea Ellas, Thessaly and Thrace. Previously recorded from locality 047 by BOROWIEC \& SALATA (2012).

\section{Camponotus aethiops (LATREILLE, 1798)}

Localities: 049, 412b, 419, 421, 432, 440, 443, 444.

Note: Recorded from Crete, the Cyclades, the Dodecanese, the East Aegean Is., Epirus, the Ionian Is., Macedonia, the Peloponnese, Sterea Ellas, Thessaly and Thrace. Previously recorded from locality 049 by BOROWIEC \& SALATA (2012).

\section{Camponotus candiotes EMERY, 1894}

Note: Recorded from the island of Skopelos by FINZI (1928). This record needs confirmation because recent materials have shown that $C$. candiotes is a southern species, known from Crete, the Dodecanese and the southern Aegean Islands. In central and northern Greece (the Ionian Islands, Epirus, southern Macedonia), areas close to Thessaly, an undescribed species has been collected that is closely related to Camponotus piceus and C. candiotes. The record by FINZI (1928) is probably based on a misidentification.

\section{Camponotus dalmaticus (NYLANDER, 1849)}

Localities: 055, 056, 412, 412b, 419, 420, 421.

Note: Recorded from the East Aegean Is., the Ionian Is., Macedonia, the Peloponnese, Sterea Ellas, Thessaly and Thrace. Previously recorded from localities 055, 056 by BOROWIEC \& SALATA (2012). 


\section{Camponotus fallax (NYLANDER, 1856)*}

Locality: 413 .

Note: Recorded from the East Aegean Is., the Ionian Is., Macedonia, Peloponnese and Thrace. New to Thessaly.

\section{Camponotus gestroi EMERY, 1878*}

Locality: 421 .

Note: Recorded from Crete, the Cyclades, the Dodecanese, East Aegean Is., Ionian Is., Macedonia, the Peloponnese and Thrace. New to Thessaly.

\section{Camponotus ionius EMERY, 1920}

Localities: 048, 053, 054, 418, 422, 433.

Note: Recorded from the Cyclades, the Dodecanese, the East Aegean Is., the Ionian Is., Macedonia, the Peloponnese, Sterea Ellas, Thessaly and Thrace. Previously recorded from localities $048,053,054$ by BOROWIEC \& SALATA (2012).

\section{Camponotus lateralis (OLIVIER, 1792)}

Localities: 048, 053, 055, 056, 412, 412b, 414, 415, 416, 421, 429, 439, 444.

Note: Recorded from Crete, the Cyclades, the Dodecanese, the East Aegean Is., Epirus, the Ionian Is., Macedonia, the Peloponnese, Sterea Ellas, Thessaly and Thrace. Previously recorded from localities 048, 053, 055, 056 by BOROWIEC \& SALATA (2012).

\section{Camponotus ligniperda (LATREILLE, 1802)*}

Localities: 427, 437, 441.

Note: Recorded from Epirus, Macedonia, the Peloponnese and Sterea Ellas. New to Thessaly.

\section{Camponotus oertzeni FOREL, 1889*}

Localities: 419, 426, 427, 431, 440.

Note: Recorded from the Dodecanese, the East Aegean Is., Epirus, the Ionian Is., Macedonia, the Peloponnese and Thrace. New to Thessaly.

\section{Camponotus piceus (LEACH, 1825)}

Localities: 049, 053, 056, 414, 419, 428, 429, 432, 436, 437, 438, 439, 440, 444. 
Note: Recorded from Crete, the Cyclades, the Dodecanese, the East Aegean Is., Epirus, the Ionian Is., Macedonia, the Peloponnese, Sterea Ellas, Thessaly and Thrace. Previously recorded from localities 049, 053, 056 by BOROWIEC \& SALATA (2012).

\section{Camponotus vagus (SCOPOLI, 1763)}

Localities: 049, 055, 056, 414, 422, 425, 427.

Note: Recorded from the East Aegean Is., Epirus, the Ionian Is., Macedonia, Peloponnese, Sterea Ellas, Thessaly and Thrace. Previously recorded from locality 049 by BOROWIEC \& SALATA (2012).

\section{Cataglyphis aenescens (NYLANDER, 1849)*}

Locality: 432 .

Note: Recorded from the Cyclades, the East Aegean Is., Macedonia, Peloponnese and Sterea Ellas. New to Thessaly.

\section{Cataglyphis nodus (BRULLÉ, 1833)}

Localities: 053, 414, 415, 416, 418, 421, 438.

Note: Recorded from Crete (probably erroneously), the Dodecanese, the East Aegean Is., Epirus, the Ionian Is., Macedonia, the Peloponnese, Sterea Ellas, Thessaly and Thrace. Previously recorded from locality 053 by BOROWIEC \& SALATA (2012).

\section{Chalepoxenus muellerianus (FINZI, 1922)}

Note: Social parasite or various Temnothorax MAYR, 1861 species recorded from Kalambaka by BUSCHINGER et al. (1988). In Greece recorded from Crete, Epirus, the Ionian Is., Macedonia, the Peloponnese and Sterea Ellas.

\section{Colobopsis truncata (SPINOLA, 1808)}

Localities: 055, 056, 412b, 413, 420, 423.

Note: Recorded from Crete, the Dodecanese, the East Aegean Is., the Ionian Is., Macedonia, Sterea Ellas, Thessaly, Peloponnese and Thrace. Previously recorded from localities 055,056 by BOROWIEC \& SALATA (2012).

\section{Crematogaster ionia FOREL, 1911}

Locality: 053 .

Note: Recorded from Crete, the Cyclades, the Dodecanese, the East Aegean Is., Epirus, the Ionian Is., Macedonia, the Peloponnese, Sterea Ellas, Thessaly and Thrace. 


\section{Crematogaster lorteti FOREL, 1910* (Fig. 1)}

Localities: $420,423$.

Note: A rare species, recorded from the East Aegean Is., Macedonia, Sterea Ellas and Thrace. New to Thessaly.

\section{Crematogaster schmidti (MAYR, 1853)}

Localities: 056, 412, 412b, 415, 418, 419, 420, 421, 429, 439, 444, 445.

Note: Recorded from Crete, the Cyclades, the Dodecanese, the East Aegean Is., the Ionian Is., Macedonia, the Peloponnese, Sterea Ellas, Thessaly and Thrace. Previously recorded from locality 056 by BOROWIEC \& SALATA (2012).

\section{Crematogaster sordidula (NYLANDER, 1849)}

Localities: $047,053,421$.

Note: Recorded from Crete, the Cyclades, the Dodecanese, the East Aegean Is., the Ionian Is., Macedonia, the Peloponnese, Sterea Ellas, Thessaly and Thrace. Previously recorded from localities 047, 053 by BOROWIEC \& SALATA (2012).

\section{Dolichoderus quadripunctatus (LINNAEUS, 1771)}

Localities: 056, 412, 412b, 415, 417, 419, 420, 423, 429, 444.

Note: Recorded from the East Aegean Is., Epirus, the Ionian Is., Macedonia, the Peloponnese, Thessaly and Thrace. Earlier records from locality 056 by BOROWIEC $\&$ SALATA (2012).

\section{Formica cinerea MAYR, 1853}

Note: Recorded generally from Thessaly under the names $F$. balcanina PETROV \& CollingwoOD, 1993 and $F$. cinerea by LEGAKIS (2011), but without any bibliographic reference. Recent materials showed that $F$. cinerea is northern species, known from Epirus, Thrace and Macedonia south to the central parts of Pieria district. Its occurrence in Thessaly thus needs to be confirmed.

\section{Formica clara FOREL, 1886*}

Locality: 436 .

Note: Recorded from the East Aegean Is., Macedonia, the Peloponnese and Thrace. New to Thessaly. 

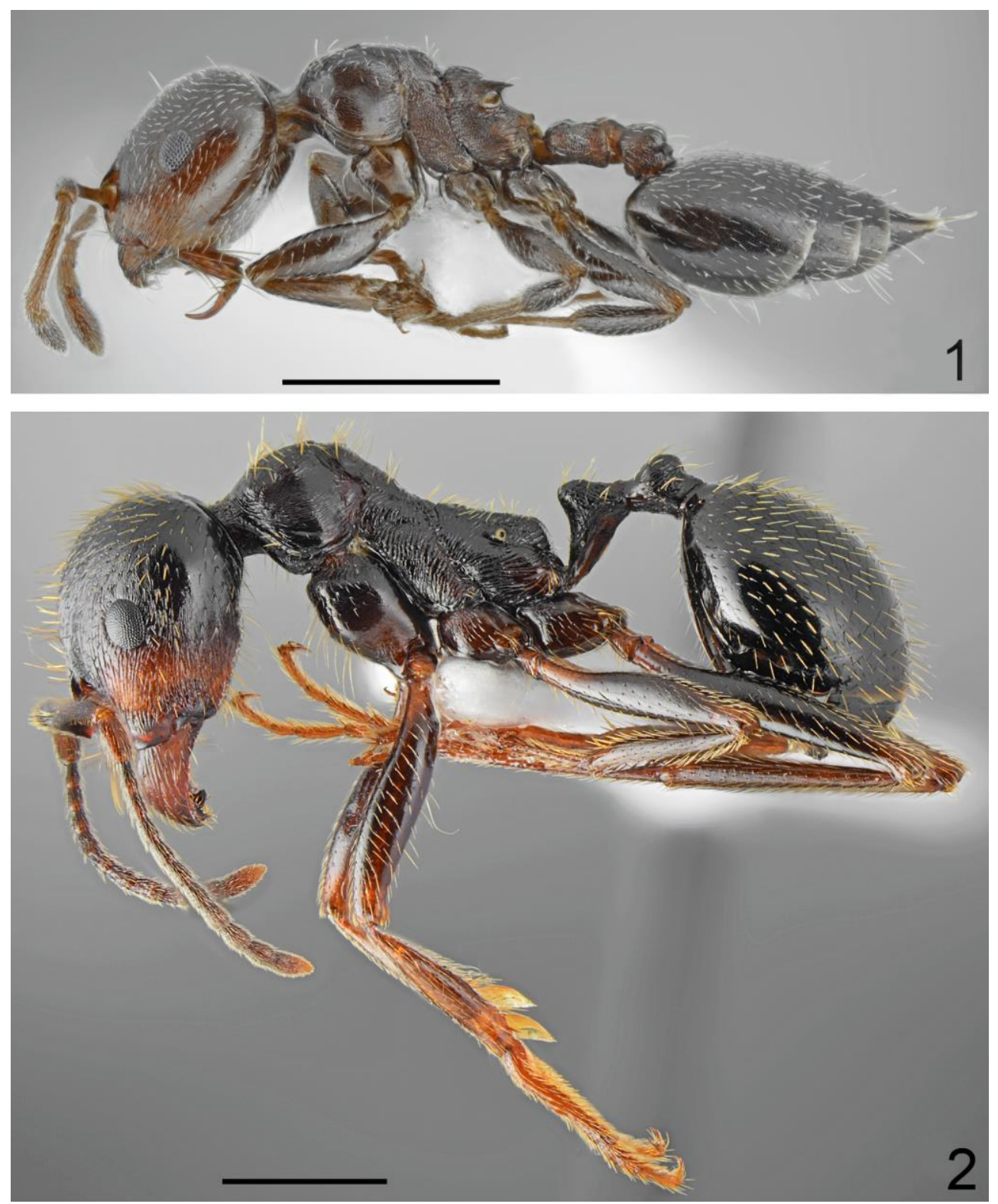

Fig. 1, 2. 1. Crematogaster lorteti FOREL, 1910, worker; 2. Messor cf. structor (LATREILLE, 1798) major worker (scale bar $=1 \mathrm{~mm})$. 


\section{Formica cunicularia LATREILLE, 1798*}

Localities: 412, 412b, 436, 438, 440, 443, 444.

Note: Recorded from Crete, the East Aegean Is., Epirus, Macedonia, Sterea Ellas, the Peloponnese and Thrace. New to Thessaly.

\section{Formica fusca LinNAEUS, 1758*}

Localities: 414, 419, 422, 426, 427, 432, 438, 441.

Note: Recorded from Epirus, the Ionian Is., Macedonia, the Peloponnese and Thrace. New to Thessaly.

\section{Formica gagates LATREILLE, 1798}

Localities: 053, 056, 414, 415, 416, 417, 422, 429, 439, 444.

Note: Recorded from Epirus, the Ionian Is., Macedonia, Sterea Ellas, Thessaly, the Peloponnese and Thrace. Earlier records from localities 053, 056 by BOROWIEC \& SALATA (2012).

\section{Formica pratensis RETZIUS, 1783*}

Localities: $426,436$.

Note: Recorded from Macedonia and Thrace. New to Thessaly.

32. Formica rufibarbis FABRICIUS, 1793

Localities: $049,426,428$.

Note: Recorded from the Cyclades, Epirus, Macedonia, Sterea Ellas, Thessaly and Thrace. Previously recorded from locality 049 by BOROWIEC \& SALATA (2012).

\section{Formica sanguinea LATREILLE, 1798*}

Localities: $426,441$.

Note: Recorded from Macedonia, the Peloponnese and Thrace. New to Thessaly.

34. Lasius alienus (FÖRSTER, 1850)

Localities: 049, 412b, 414, 419, 420, 422, 426, 428, 432, 437, 438, 440, 442, 443, 444.

Note: Recorded from the Cyclades, the East Aegean Is., Epirus, Macedonia, the Peloponnese, Sterea Ellas, Thessaly and Thrace. Previously recorded from locality 049 by BOROWIEC \& SALATA (2012). 


\section{Lasius bombycina SEIFERT \& GALKOWSKI, 2016}

Locality: 049, 436.

Note: Recorded from Crete, the Dodecanese, the East Aegean Is., the Ionian Is., Macedonia, the Peloponnese, Thessaly and Thrace. Previously recorded as Lasius paralienus SEIFERT, 1992 from locality 049 by BOROWIEC \& SALATA (2012).

\section{Lasius brunneus (LATREILLE, 1798)}

Localities: 053, 412, 421, 424, 443.

Note: Recorded from the East Aegean Is., the Ionian Is., Macedonia, Sterea Ellas, Thessaly, the Peloponnese and Thrace. Previously recorded from locality 053 by BOROWIEC \& SALATA (2012).

\section{Lasius citrinus EMERY, 1922}

Note: Recorded generally from Thessaly by LEGAKIS (2011), but without any bibliographic reference. Information based on an unpublished list, compiled by Cedric A. COLLINGWOOD, of Greek ants, now preserved in the Zoological Museum, University of Athens. The list contains many errors, due mostly to misidentifications and misinterpreted taxa. The general distribution of $L$. citrinus in Europe and the recent record from Greek Macedonia (BOROWIEC \& SALATA 2012) indicate that its occurrence in Thessaly is possible.

\section{Lasius emarginatus (OLIVIER, 1791)}

Localities: 053, 054, 056, 412, 412b, 413, 414, 415, 416, 417, 420, 423, 424, 425, 426, 427, 428, 429, 430, 431, 437, 438, 439, 441, 443, 444

Note: Recorded from the Dodecanese, Epirus, the Ionian Is., Macedonia, the Peloponnese, Sterea Ellas and Thessaly. Previously recorded from localities 053, 054, 056 by BOROWIEC \& SALATA (2012).

\section{Lasius flavus (FABRICIUS, 1782)}

Localities: $436,441$.

Note: Recorded from the East Aegean Is., Epirus, the Ionian Is., Macedonia, the Peloponnese, Sterea Ellas, Thessaly and Thrace.

\section{Lasius jensi SEIFERT, 1982*}

Localities: $426,436$.

Note: Recorded from Macedonia and Thrace. New to Thessaly. 


\section{Lasius lasioides (EMERY, 1869)}

Localities: 053, 419, 420, 426, 433.

Note: Recorded from the Cyclades, the Dodecanese, the East Aegean Is., the Ionian Is., Macedonia, the Peloponnese, Thessaly and Thrace.

\section{Lasius myops FOREL, 1894*}

Locality: 419 .

Note: Recorded from Macedonia and Thrace. New to Thessaly.

\section{Lasius myrmidon MEI, 1998}

Localities: 048, 419.

Note: Recorded from the Peloponnese, Sterea Ellas and Thessaly. Endemic to Greece. Previously recorded from locality 048 by BOROWIEC \& SALATA (2012).

\section{Lasius cf. neglectus}

Localities: 426, 441.

Note: At first glance, samples from the alpine pastures of Mt Olympus and Mt Ossa are similar to Lasius neglectus VAN LOOM, BOOMSMA \& ANDRASFALVY, 1990 but differ in some morphometric details. The taxonomic status of these samples requires further morphological and molecular studies. At present their status is unclear.

\section{Lasius nitidigaster SEIFERT, 1996 (Fig. 3)}

Locality: 049 .

Note: Recorded only from Thessaly, from the locality noted above (BOROWIEC \& SALATA 2012).

\section{Lepisiota frauenfeldi (MAYR, 1855)}

Localities: 048, 054, 418, 432, 433.

Note: Recorded from Crete, the Dodecanese, the East Aegean Is., the Ionian Is., Macedonia, the Peloponnese, Sterea Ellas, Thessaly and Thrace. Previously recorded as Lepisiota melas from localities 048, 054 by BOROWIEC \& SALATA (2012). 

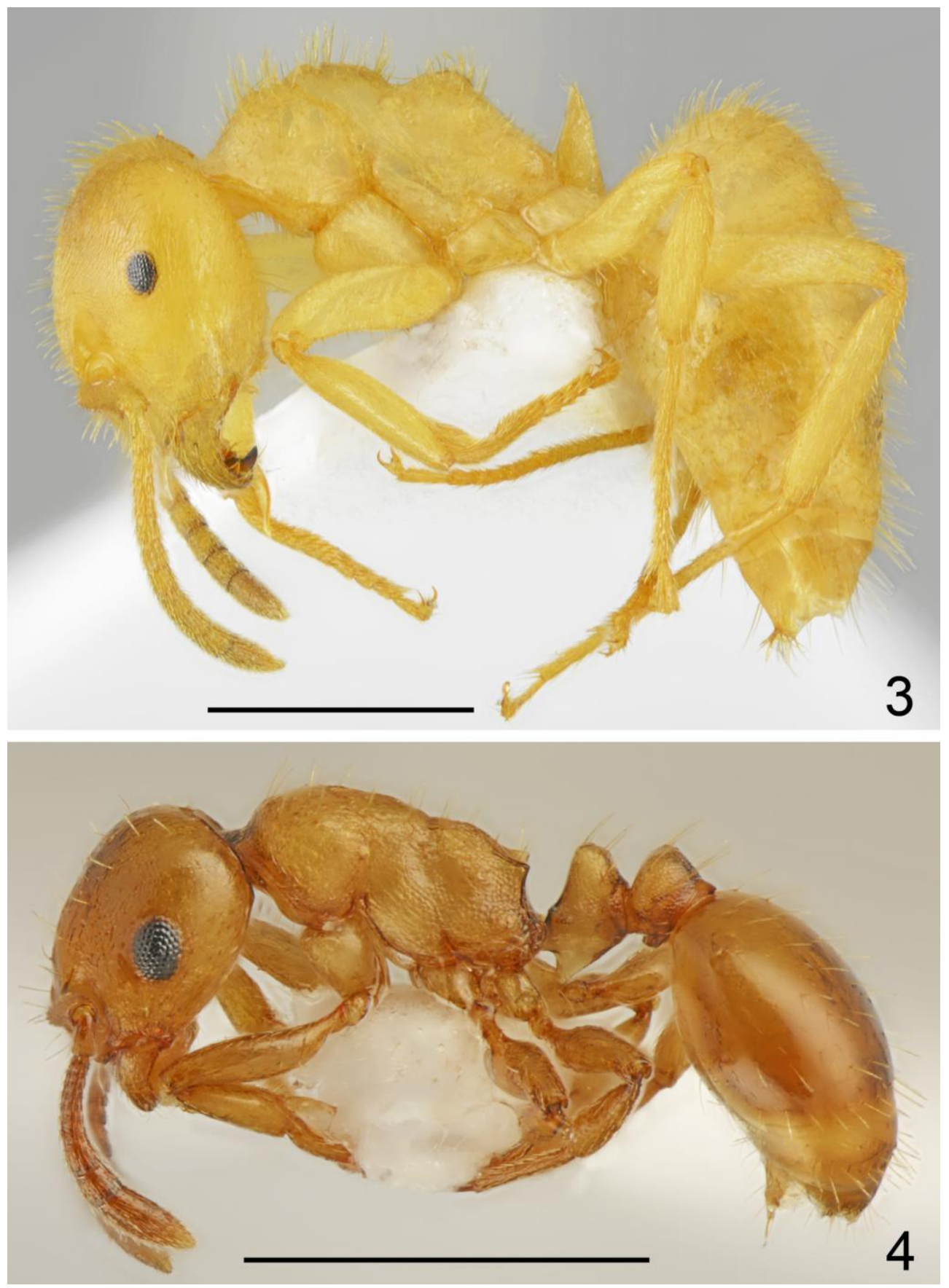

Fig. 3, 4. 3. Lasius nitidigaster SEIFERT, 1996, worker; 4. Myrmoxenus gordiagini RUZSKY, 1902, worker (scale bar $=1 \mathrm{~mm})$. 


\section{Liometopum microcephalum (PANZER, 1798)}

Localities: 049, 412, 421, 422.

Note: Recorded from the East Aegean Is., Epirus, the Ionian Is., Macedonia, the Peloponnese, Sterea Ellas, Thessaly and Thrace. Previously recorded from locality 049 by BOROWIEC \& SALATA (2012).

\section{Manica rubida (LATREILLE, 1802)}

Note: Recorded generally from Thessaly by LEGAKIS (2011) but with no bibliographic reference. From the general distribution of $M$. rubida in Europe and the recent record from Greek Macedonia (BOROWIEC \& SALATA unpublished data), one can infer its possible occurrence in the mountains of Thessaly, especially in the Mt. Olympus massif.

\section{Messor ibericus SANTSCHI, 1925*}

Locality: 429 .

Note: According to the recent comprehensive revision, the taxon previously named Messor structor (LATREILLE, 1798) comprises five cryptic species, four of them was recorded from different parts of the Balkan Peninsula (STEINER et al. 2018). The revision showed that most records of Messor structor (LATREILLE, 1798) from Balkan Peninsula concern Messor ibericus SANTSCHI, 1925. In our material from Greece we found M. ibericus from Crete, the Dodecanese, the Ionian Is., Macedonia, and the Peloponnese but probably occurs in all Greek provinces. New to Thessaly.

\section{Messor hellenius AgOSTI \& CollingwoOd, 1987}

Localities: 047, 049, 056, 412, 412A, 412B, 418, 444.

Note: Recorded from Crete, the Cyclades, the Dodecanese, the East Aegean Is., Macedonia, the Peloponnese, Sterea Ellas, Thessaly and Thrace. Previously recorded as Messor capitatus from locality 056 by BOROWIEC \& SALATA (2012).

\section{Messor mcarthuri STEINER et al., 2018}

Localities: 047, 049, 053, 426, 440.

Note: See note under Messor ibericus SANTSCHI, 1925. In our material we have this species from Crete, the Cyclades, the Dodecanese, the East Aegean Is., the Ionian Is., Macedonia, the Peloponnese, Sterea Ellas, Thessaly and Thrace. Previously recorded as Messor muticus from localities 047, 049, 053 by BOROWIEC \& SALATA (2012).

$$
\text { 52. Messor structor (LATREILLE, 1798)* (Fig. 2) }
$$

Localities: 436,443 . 
Note: See note under Messor ibericus SANTSCHI, 1925. This species appears to be rare in Greece, it was recorded from Epirus as Messor cf. clivorum (BOROWIEC \& SALATA 2018). We have also unpublished data from Peloponnese and Sterea Ellas. New to Thessaly.

\section{Messor wasmanni KRAUSSE, 1910}

Localities: 047, 048, 053, 440.

Note: Recorded from Crete, the Cyclades, the Dodecanese, the East Aegean Is., Epirus, the Ionian Is., Macedonia, the Peloponnese, Sterea Ellas, Thessaly and Thrace. Previously recorded from localities 047, 048, 053 by BOROWIEC \& SALATA (2012).

\section{Myrmecina graminicola (LATREILLE, 1802)}

Locality: 055 .

Note: Recorded from Crete, the Cyclades, the Dodecanese, Epirus, the Ionian Is., Macedonia, the Peloponnese, Sterea Ellas, Thessaly and Thrace. Previously recorded from locality 055 by BOROWIEC \& SALATA (2012).

\section{Myrmica hellenica FINZI, 1926*}

Locality: 443 .

Note: Recorded from the Ionian Is., Macedonia, the Peloponnese and Thrace. New to Thessaly.

\section{Myrmica lobicornis NYLANDER, 1846*}

Locality: 441 .

Note: Recorded only from Macedonia. New to Thessaly.

57. Myrmica sabuleti MEINERT, 1861*

Localities: 432, 437.

Note: Recorded from the Dodecanese, Epirus, Macedonia, Sterea Ellas and Thrace. New to Thessaly.

\section{Myrmica scabrinodis NYLANDER, 1846*}

Localities: 430, 436, 438, 441.

Note: Recorded from the Ionian Is., Macedonia, the Peloponnese and Thrace. New to Thessaly. 


\section{Myrmica sulcinodis NYLANDER, 1846}

Note: Its presence has been confirmed in Macedonia and Sterea Ellas. In addition, recorded generally from Thessaly by LEGAKIS (2011), but without any bibliographic reference. According to the general distribution of M. sulcinodis in Europe and an old record from the Vradoussia Mts. in Sterea Ellas (FOREL 1889), its occurrence in the mountains of Thessaly is possible, especially in the Mt. Olympus, Mt. Ossa and Mt. Pelion massifs.

\section{Myrmoxenus gordiagini RUZSKY, 1902* (Fig. 4)}

Locality: 415 .

Note: A social parasite on various Temnothorax species, recorded only from Sterea Ellas. New to Thessaly.

\section{Myrmoxenus ravouxi (ANDRÉ, 1896)*}

Locality: 441 .

Note: A social parasite on various Temnothorax species, recorded from Macedonia and the Peloponnese. New to Thessaly.

\section{Pheidole cf. pallidula}

Localities: 048, 049, 053, 055, 056, 412, 412b, 416, 418, 419, 420, 421, 433, 444.

Note: Recorded from Crete, the Cyclades, the Dodecanese, the East Aegean Is., Epirus, the Ionian Is., Macedonia, the Peloponnese, Sterea Ellas, Thessaly and Thrace. Mediterranean populations of the taxon named Pheidole pallidula (NYLANDER, 1849) have recently been divided into four species, three of them recorded in Greece and the Peloponnese (SEIFERT 2016). This point of view is still being debated, owing to the great local variability of this very common ant. Previously recorded from localities 048, 049, 053, 055, 056 by BOROWIEC \& SALATA (2012).

\section{Plagiolepis pallescens sensu RADCHENKO (1996)}

Note: Recorded generally from Thessaly by LEGAKIS (2011), but without any bibliographic reference. Its general distribution in Europe and recent records from Macedonia and Sterea Ellas (BOROWIEC \& SALATA 2012) suggest that its occurrence in Thessaly is possible, especially in dry habitats. Recorded from Crete, the Cyclades, the Dodecanese, the East Aegean Is., the Ionian Is., Macedonia, the Peloponnese, Sterea Ellas and Thrace. The name Plagiolepis pallescens sensu RADCHENKO (1996) is tentative, because RADCHENKO (1996) misinterpreted this taxon in his review of Plagiolepis MAYR, 
1861 from the Central and Southern Palaearctic. This problem was discussed by BRAČKO et al. (2016); at the moment this species has no formal name.

\section{Plagiolepis pygmaea (LATREILLE, 1798)}

Localities: 048, 056, 412, 413, 414, 415, 416, 419, 420, 421, 422, 432, 440, 444.

Note: Recorded from Crete, the Cyclades, the Dodecanese, the East Aegean Is., Epirus, the Ionian Is., Macedonia, the Peloponnese, Sterea Ellas, Thessaly and Thrace. Previously recorded from localities 048, 056 by BOROWIEC \& SALATA (2012).

\section{Plagiolepis taurica SANTSCHI, 1920}

Localities: 418, 419, 426, 433.

Note: Recorded from Crete, the Cyclades, the Dodecanese, the East Aegean Is., the Ionian Is., Macedonia, the Peloponnese, Thessaly and Thrace.

\section{Ponera coarctata (LATREILLE, 1802)}

Locality: 417.

Note: Recorded from Epirus, the Ionian Is., Macedonia, Sterea Ellas, the Peloponnese, Thessaly and Thrace.

\section{Ponera testacea EMERY, 1895*}

Locality: 422.

Note: Recorded from the Ionian Is., Macedonia, the Peloponnese and Thrace. New to Thessaly.

\section{Prenolepis nitens (MAYR, 1853)}

Localities: 412b, 413, 419, 428, 444.

Note: Recorded from the East Aegean Is., Epirus, the Ionian Is., Macedonia, Sterea Ellas, the Peloponnese, Thessaly and Thrace.

\section{Proformica cf. oculatissima}

Localities: 426, 443.

Note: Specimens from both Thessalian localities differ from specimens of Proformica striaticeps (FoREL, 1910), the only well-known Greek Proformica species. The taxonomic status of $P$. oculatissima (FoREL, 1886), another species described from Greece (Sterea Ellas) and known only from a single male specimen, is unclear. Because we collected only minor workers in Thessaly, their comparison with the P. oculatissima type does not 
guarantee a definitive identification. On the other hand, the high altitude of the locality of our samples also suggests that we may be dealing with an undescribed species.

\section{Solenopsis cf. lusitanica}

Localities: $055,415,444$.

Note: Crete, the Cyclades, the Dodecanese, the East Aegean Is., Epirus, Macedonia, the Peloponnese, Thessaly and Thrace. The status of most European species of the genus Solenopsis WeSTWOOD, 1840 requires extensive revision. GALKOWSKI et al. (2010) redescribed Solenopsis fugax and suggested that four distinct species groups occur in Europe and the Mediterranean region. They also suggested that several taxa proposed by BERNARD (1950) are probably synonyms, but they did not take any formal decisions regarding the nomenclature. Our samples from Thessaly, characterized by shorter hairs on the mesosoma and small gynes, belong to the Solenopsis lusitanica group as proposed by GALKOWSKI et al. (2010). According to these authors, the group comprises three taxa described from the western Mediterranean Basin, but we cannot exclude the presence of other, undescribed species in the eastern Mediterranean. Previously recorded as Solenopsis wolfi EMERY, 1915 from locality 055 by BOROWIEC \& SALATA (2012).

\section{Stenamma debile (FÖRSTER, 1850)}

Note: Recorded generally from Thessaly by LEGAKIS (2011), but without any bibliographic reference. Recently recorded from the southern slope of Mt. Pelion (Volos), and the north-western slope of Mt. Ossa by Rigato (2011). Recorded from Macedonia, the Peloponnese, Sterea Ellas and Thessaly; the record from the Peloponnese requires confirmation.

\section{Stenamma striatulum EMERY, 1895}

Note: Recorded generally from Thessaly by LEGAKIS (2011), but without any bibliographic reference. Recently recorded from the southern slope of Mt. Pelion (Volos) by RIGATO (2011).

\section{Tapionoma erraticum (LATREILLE, 1798)}

Localities: 047, 049, 054, 418, 419, 421, 426, 433, 437, 438, 441, 442, 444.

Note: Recorded from Crete, the Cyclades, the Dodecanese, the East Aegean Is., Epirus, the Ionian Is., Macedonia, Peloponnese, Sterea Ellas, Thessaly and Thrace. Previously recorded from localities 049, 054 by BOROWIEC \& SALATA (2012). 


\section{Tapinoma simrothi KRAUSSE, 1911}

Note: Recorded generally from Thessaly by LEGAKIS (2011), but without any bibliographic reference. Tapinoma simrothi is generally a southern species and its occurrence in Thessaly needs confirmation.

\section{Temnothorax affinis (MAYR, 1885)*}

Locality: 425 .

Note: Recorded from the Aegean Islands, the Cyclades, the Ionian Is., Macedonia, Sterea Ellas and Thrace, but a recent study of Temnothorax from Greece suggests that most records are probably misidentifications. We have confirmed records only from the Ionian Islands (unpublished data). New to Thessaly.

\section{Temnothorax cf. aveli*}

Localities: 412b, 413, 415, 444.

Note: An undescribed species, very distinct from all other Greek taxa. In our collection we also have specimens of this taxon collected from Epirus, the Ionian Islands and the Peloponnese. Its description is in preparation. New to Thessaly.

\section{Temnothorax bulgaricus (FOREL, 1892)*}

Localities: 419, 420, 421, 429.

Note: Recorded from the Dodecanese, the East Aegean Is., the Ionian Is., Macedonia, the Peloponnese and Thrace. New to Thessaly.

\section{Temnothorax crasecundus SEIFERT \& CsŐsz, 2015*}

Localities: 413, 415, 420, 423, 424, 425, 427, 429, 430, 431, 437, 443, 444.

Note: Recorded from Macedonia, the Peloponnese and Thrace. New to Thessaly.

$$
\text { 79. Temnothorax exilis (EMERY, 1869)* }
$$

Localities: 418, 419, 420, 421, 432, 433.

Note: Recorded from Crete, the Cyclades, the Dodecanese, the East Aegean Is., the Ionian Is., Macedonia, the Peloponnese, Sterea Ellas and Thrace. New to Thessaly.

\section{Temnothorax flavicornis (EMERY, 1870)*}

Locality: 433 .

Note: Recorded from the Ionian Is., Macedonia, the Peloponnese. New to Thessaly. 


\section{Temnothorax cf. graecus (Fig. 5)}

Localities: 056, 419, 420, 421, 422, 428, 432, 433, 440.

Note: This is a new species from the Temnothorax graecus complex. Its description is in preparation. Previously recorded as Temnothorax graecus (FOREL, 1911) from locality 056 by BOROWIEC \& SALATA (2012).

\section{Temnothorax helenae CsÖsZ, HEINZE \& MIKÓ, 2015}

Locality: 420 .

Note: Recorded from the Cyclades, Macedonia, Sterea Ellas, the Peloponnese, Thessaly and Thrace.

\section{Temnothorax lichtensteini (BONDROIT, 1918)}

Localities: 413, 417, 420, 425, 427, 428, 429.

Note: Recorded from Epirus, the Ionian Islands, Macedonia, Sterea Ellas, Thessaly and Thrace.

\section{Temnothorax melanocephalus (EMERY, 1870)* (Fig. 7)}

Localities: 441, 442, 443.

Note: The status of the Greek species belonging to the Temnothorax nigriceps-tuberumunifasciatus complex is unclear. RADCHENKO (2016) restored species rank to Temnothorax melanocephalus (EMERY, 1870) and suggested that this taxon is widespread in the Mediterranean area, from Corsica to Crimea. He also noted its occurrence in Greece. We have examined specimens of true T. melanocephalus from Corsica (the terra typica of this taxon) and, in our opinion, the specimens from two samples from Mt. Olympus appear to represent this taxon or a species very close to it. New to Thessaly.

\section{Temnothorax cf. melanocephalus* (Fig. 8)}

Localities: 443.

Note: There are three nest samples of species, belonging to the T. melanocephalus group, which differ from $T$. melanocephalus in their much longer propodeal spines. They were collected on Mt. Olympus, at the same locality as the typical form. The status of this morphospecies will be clarified following revision of the Greek members of the Temnothorax nigriceps-tuberum-unifasciatus complex. New to Thessaly. 

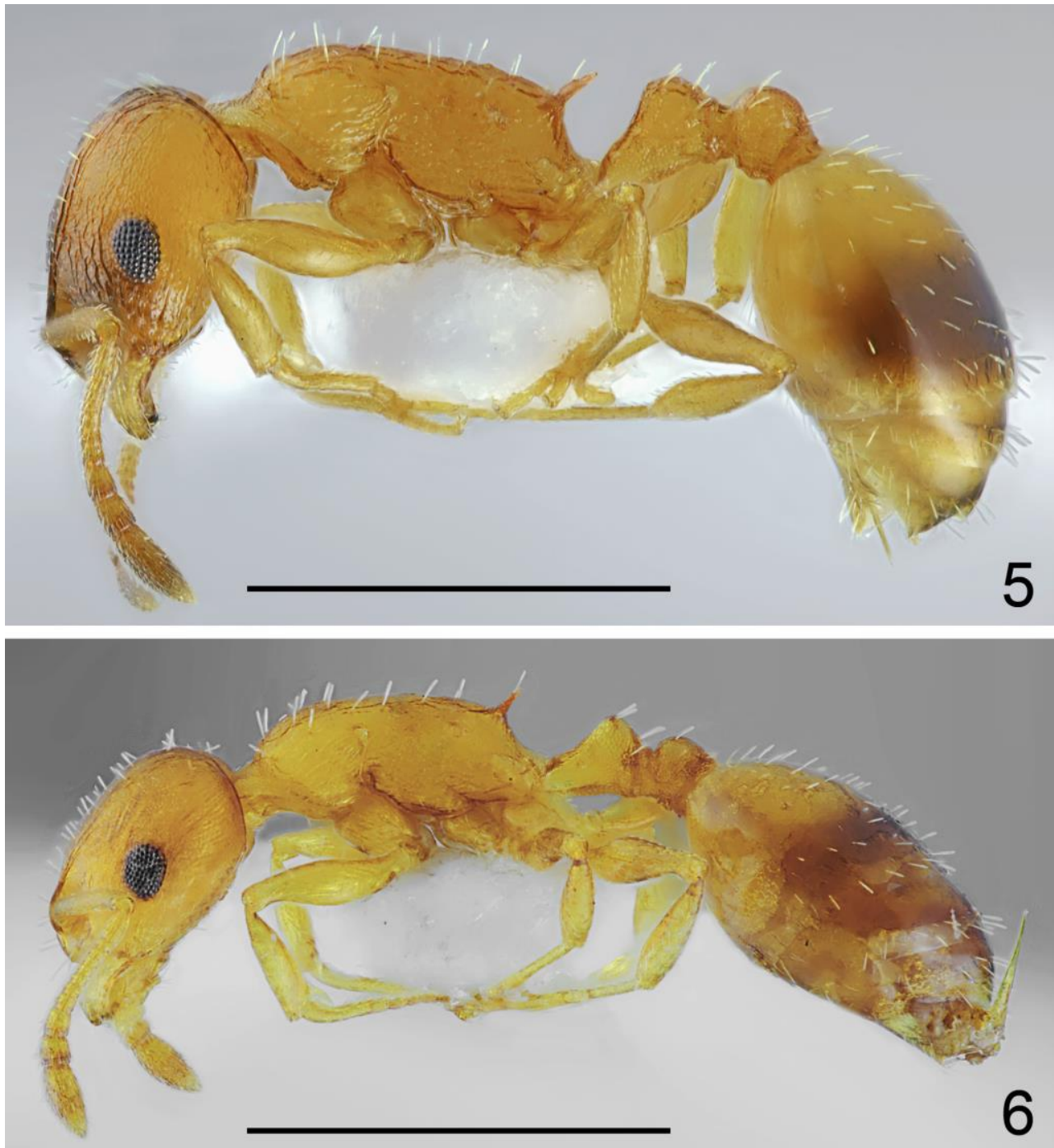

Fig. 5, 6. 5. Temnothorax cf. graecus in litt., worker; 6. Temnothorax tauricus (RUZSKY, 1902), worker (scale bar $=1 \mathrm{~mm})$. 

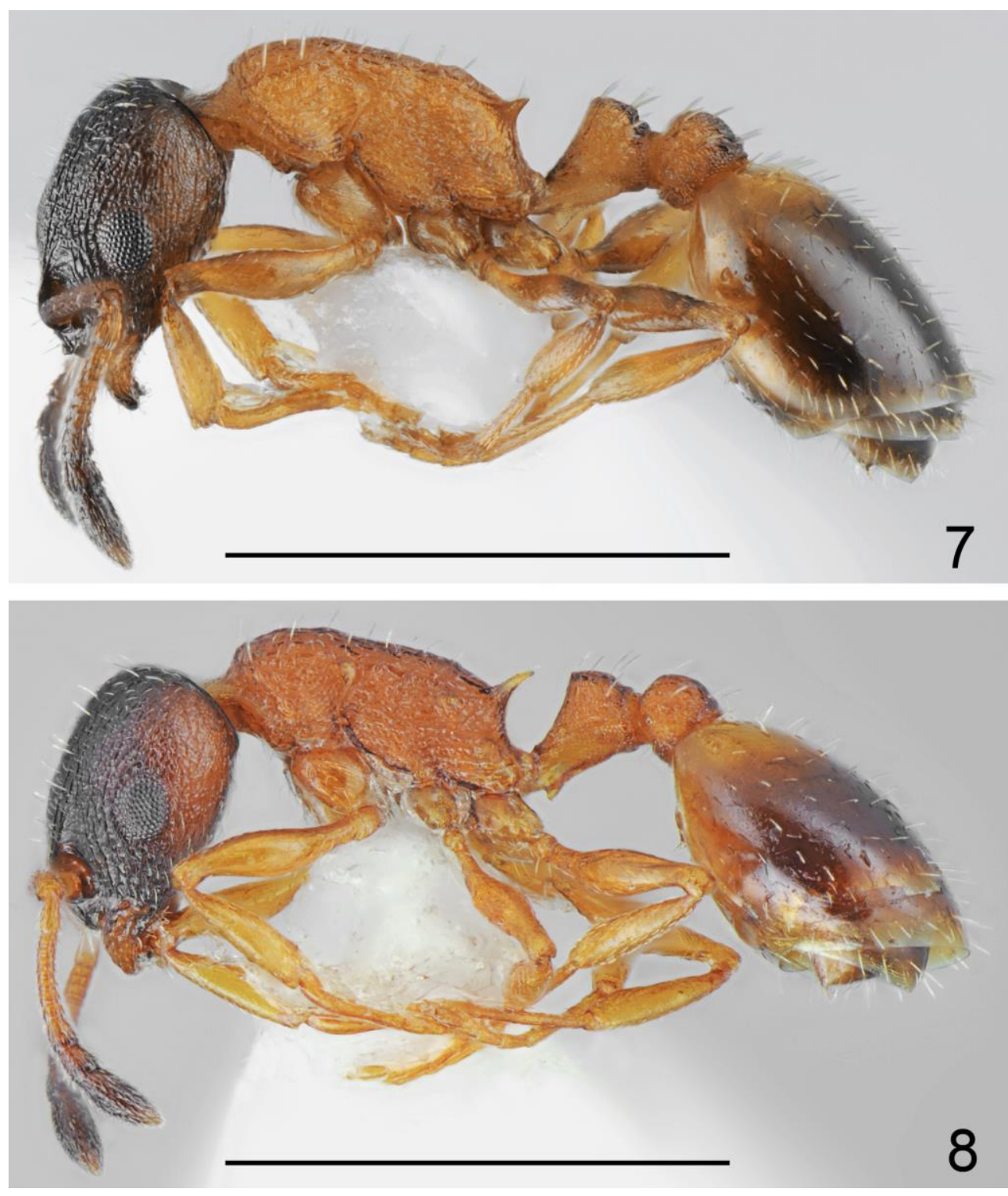

Fig. 7, 8. 7. Temnothorax melanocephalus (EMERY, 1870), worker; 8. Temnothorax cf. melanocephalus, worker (scale bar $=1 \mathrm{~mm})$. 


\section{Temnothorax cf. nigriceps*}

Locality: 426 .

Note: The status of the Greek members of the Temnothorax nigriceps-tuberumunifasciatus complex is unclear. At first glance, the samples from the alpine pastures of Mt. Ossa are similar to samples of T. nigriceps from central Europe but differ in a few details of body colouration and sculpture. Members of the T. nigriceps group have been recorded from the Ionian Is., Macedonia, the Peloponnese and Thrace, but according to recent material they represent at least three distinct morphospecies. Their status will be clarified following revision of all Greek members of the Temnothorax nigriceps-tuberumunifasciatus complex. New to Thessaly.

\section{Temnothorax recedens (NYLANDER, 1856)}

Localities: 048, 418, 419, 420, 421, 433, 444

Note: Recorded from Crete, the Dodecanese, the East Aegean Is., Epirus, the Ionian Is., Macedonia, the Peloponnese, Sterea Ellas, Thessaly and Thrace.

\section{Temnothorax semiruber (ANDRÉ, 1881)}

Localities: 049, 432, 443.

Note: Recorded from Crete, the Cyclades, the Dodecanese, the East Aegean Is., Macedonia, the Peloponnese, Sterea Ellas, Thessaly and Thrace. Previously recorded from locality 049 by BOROWIEC \& SALATA (2012).

\section{Temnothorax sordidulus (MÜLLER, 1923)*(Fig. 9)}

Locality: 426.

Note: Temnothorax sordidulus was recorded from Macedonia (BOROWIEC \& SALATA 2012) but Csösz et al. (2015) suggested that the true T. sordidulus is endemic to the Dinaric Alps. After examining extensive material from the Balkan Peninsula, they suggested that all records of this species from beyond the Dinaric Alps related to misidentified, dark specimens of Temnothorax tergestinus (FINZI, 1928). Following reexamination of the Macedonian material, we concur with this observation. Surprisingly, we found two samples in recent material from Mt. Ossa with all the characters of true $T$. sordidulus. Our identification was confirmed by S. Csősz. This species thus appears to have a wider distribution in the Balkan Peninsula than suggested in the revision. New to Greece and Thessaly. 


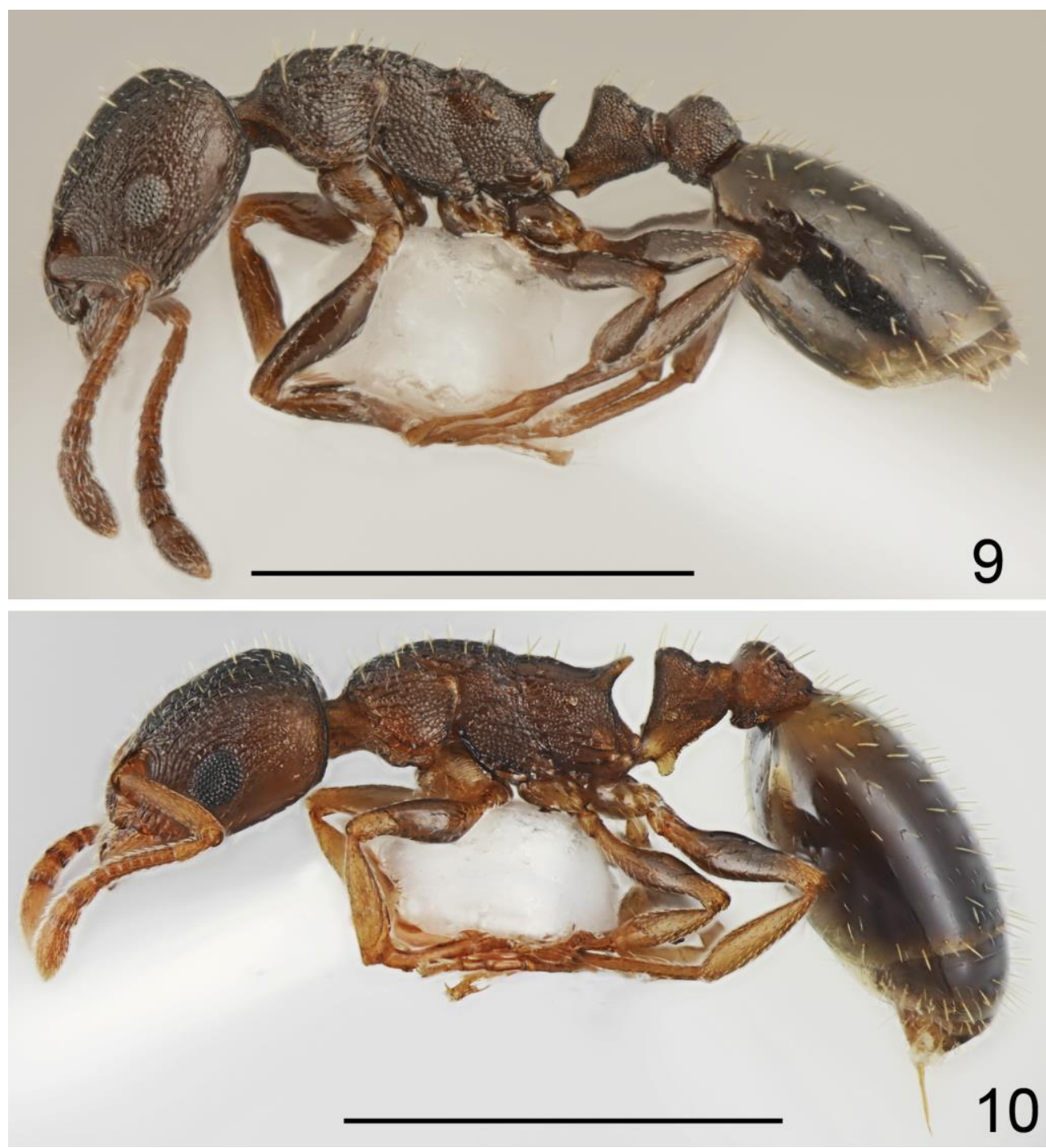

Fig. 9, 10. 9. Temnothorax sordidulus (MüLLER, 1923), worker; 10. Temnothorax tergestinus (FINZI, 1928), worker (scale bar $=1 \mathrm{~mm}$ ).

90. Temnothorax strymonensis CSŐSZ, SALATA \& BOROWIEC, 2018

Locality: 049.

Note: Recently recorded from this locality by BOROWIEC \& SALATA (2012) under the name Temnothorax interruptus (SCHENCK, 1852). Revision of the T. interruptus group has 
shown that two other species occur in Greece (Csösz et al. 2018). Recorded from Epirus, the Ionian Is., Macedonia, the Peloponnese, Thessaly and Thrace.

\section{Temnothorax subtilis CsŐsZ, HeINZE \& MIKÓ, 2015}

Localities: 412B, 413, 415, 416, 417, 421, 422, 423, 429, 436, 438, 439.

Note: Recorded from Crete, the Peloponnese, Thessaly and Thrace.

\section{Temnothorax tauricus (RUZSKY, 1902)* (Fig. 6)}

Localities: 412b, 414, 415, 426, 443.

Note: For many years, the only records of this species were from Crimea, but RADCHENKO (2016) has recently recorded it in the Caucasus, Armenia and Bulgaria. We examined material of $T$. tauricus from Crimea (the terra typica of this species) and our samples agree well with the topotypes. New to Greece and Thessaly.

\section{Temnothorax tergestinus (FINZI, 1928) (Fig. 10)}

Locality: 443 .

Note: Recorded from Epirus, Macedonia, Sterea Ellas, the Peloponnese, Thessaly and Thrace. The sample from Thessaly belongs to the extremely dark form, which in Greece is more common than the typical pale form known from central Europe. These dark forms have often been confused with Temnothorax sordidulus (MÜLLER, 1923).

\section{Temnothorax cf. tuberum}

Localities: 049, 416, 430.

Note: The Greek taxa belonging to the Temnothorax tuberum-unifasciatus complex require revision based on detailed morphometric studies. Our material from various parts of Greece suggests that more than two species related to T. tuberum (FABRICIUS, 1775) occur in this area. According to the literature, T. tuberum has been recorded from Epirus, the Ionian Is., Macedonia, the Peloponnese, Thessaly and Thrace. Previously recorded as Temnothorax tuberum from locality 049 by BOROWIEC \& SALATA (2012).

\section{Temnothorax turcicus (SANTSCHI, 1934)}

Locality: 055, 412b.

Note: Recently recorded from locality 055 by BOROWIEC \& SALATA (2012). In Greece known only from Macedonia, Thessaly and Thrace. 


\section{Temnothorax cf. unifasciatus}

Localities: 055, 056, 412b, 413, 415, 416, 417, 419, 420, 421, 422, 425, 426, 427, 428, 436, 437, 438, 440, 441, 442, 443.

Note: The Greek taxa belonging to the Temnothorax tuberum-unifasciatus complex require revision based on detailed morphometric studies. Our material from various parts of Greece suggests the occurrence of at least two species related to $T$. unifasciatus (LATREILLE, 1798) in this area. According to the literature, T. unifasciatus has been recorded from the East Aegean Is., Epirus, the Ionian Is., Macedonia, the Peloponnese, Thessaly and Thrace. Previously recorded as Temnothorax unifasciatus (LATREILLE, 1798) from localities 055,056 by BOROWIEC \& SALATA (2012).

\section{Tetramorium caespitum (LINNAEUS, 1758)}

Localities: $421,429,440$.

Note: See the comment under Tetramorium immigrans. Verified records of $T$. caespitum in Greece are from mountain localities in Epirus, Macedonia and the Peloponnese.

\section{Tetramorium chefketi FOREL, 1911}

Locality: 047.

Note: Recorded from the Aegean Islands, Crete, the Ionian Islands, Macedonia, Thessaly and Thrace.

\section{Tetramorium diomedeum EMERY, 1908}

Locality: 049 .

Note: Recorded from Crete, the Dodecanese, the East Aegean Is., the Ionian Is., Macedonia, the Peloponnese and Thessaly.

\section{Tetramorium cf. flavidulum*}

Localities: 419, 426, 428, 437, 441, 442.

Note: In the eastern part of the Mediterranean Basin the Tetramorium flavidulum group is represented by several morphospecies, with the centre of diversity in Anatolian Turkey (our unpublished data). Our material from Greece suggests the occurrence of at least two distinct species in this country. Definitive identification of the sample from Thessaly will not be possible until all the known taxa of the $T$. flavidulum group have been revised. Recorded from the East Aegean Is., the Dodecanese, the Peloponnese and Thrace. New to Thessaly. 


\section{Tetramorium hungaricum RÖSZLER, 1935}

Locality: 047.

Note: Previously recorded from this locality by BorowIEC \& SALATA (2012). In Greece known only from Macedonia and Thessaly.

\section{Tetramorium immigrans SANTSCHI, 1927}

Locality: 049, 412, 412b.

Note: Previously recorded as Tetramorium caespitum from locality 049 by BOROWIEC $\&$ SALATA (2012). The Tetramorium caespitum/impurum complex was recently revised by WAGNER et al. (2017). Our samples from Thessaly belong to at least three species, while five are known from Greece. Tetramorium immigrans is widely distributed but known mostly from urban and tourist areas. The locality in Thessaly (a tourist resort) tallies with these observations. The authors of the revision also noted this species from Crete and Thassos Island (Macedonia), but our material showed that this species occurs in almost all Greek provinces (unpublished data).

\section{Tetramorium impurum (FÖRSTER, 1850)*}

Localities: 426, 430, 438.

Note: In Greece known from Epirus, the Ionian Islands, Macedonia, the Peloponnese and Thrace. New to Thessaly.

\section{Tetramorium kephalosi SALATA \& BOROWIEC, 2017}

Localities: 049, 053, 418, 422, 444.

Note: A species recently described from Greece, formerly confused with Tetramorium semilaeve ANDRÉ, 1883. Based on new data, true $T$. semilaeve is distributed only in the western Mediterranean Basin. Recorded from Crete, the Cyclades, the Dodecanese, the East Aegean Is., Epirus, the Ionian Is., Macedonia, the Peloponnese, Sterea Ellas, Thessaly and Thrace. Previously recorded as Teramorium semilaeve from localities 049, 053 by BOROWIEC \& SALATA (2012).

\section{Tetramorium moravicum KRATOCHVIL, 1941}

Localities: 049, 054, 055, 415, 418, 426, 429, 430, 436, 437, 438, 439, 443, 444.

Note: Recorded from Epirus, Macedonia, the Peloponnese, Thessaly and Thrace. Previously recorded from localities $049,054,055$ by BOROWIEC \& SALATA (2012). 


\section{Tetramorium $\mathrm{cf}$. punicum*}

Locality: 433 .

Note: This morphospecies, probably new to science, is similar to Tetramorium punicum (SMITH, 1861) described from Israel. We have samples from the East Aegean Is., the Ionian Is. and the Peloponnese. New to Thessaly.

\section{Trichomyrmex perplexus (RADCHENKO, 1997)}

Localities: 047, 418.

Note: Recorded from Crete, the Cyclades, the Dodecanese, the East Aegean Is., the Ionian Is., Macedonia, the Peloponnese, Sterea Ellas and Thessaly. Previously recorded from locality 047 by BOROWIEC \& SALATA (2012).

\section{CONCLUSIONS}

As a consequence of our study, Thessaly belongs to the reasonably well-known Greek regions as far as its ant fauna is concerned. With 107 species recorded, Thessaly is ranked close to the Ionian Islands (107 species) and the North Aegean Islands (106 species), regions that are distinctly smaller and less habitat-diverse than Thessaly. This allows us to estimate that there are at least 20-30 as yet unrecorded species in this province. The region is a mixture of northern elements (i.e. Aphaenogaster epirotes, Camponotus dalmaticus, $C$. fallax, Formica pratensis, F. sanguinea, Lasius jensi, Myrmica lobicornis, M. sabuleti), strictly Mediterranean species (i.e. Crematogaster ionia, Lasius lasioides, Tapinoma simrothi, Temnothorax exilis, T. flavicornis, T. recedens, T. subtilis, Tetramorium kephalosi, Trichomyrmex perplexus) and alpine taxa (i.e. Myrmoxenus gordiagini, M. ravouxi, Proformica cf. oculatissima, Temnothorax melanocephalus, $T$. cf. melanocephalus, T. sordidulus). Four species are known in Greece only from localities in Thessaly: Lasius nitidigaster, Temnothorax melanocephalus, T. sordidulus and T. tauricus.

\section{ACKNOWLEDGEMENTS}

We would like to thank Jolanta ŚWIĘTOJAŃSKA (University of Wrocław) for her assistance during Lech BOROWIEC's field trips, and to Radosław PLEWA (Sękocin Stary, Poland) for one sample collected in the Trikala unit. We are grateful to the two anonymous reviewers for their valuable suggestions and corrections for improving the manuscript. 


\section{REFERENCES}

BOER P. 2013. Revision of the European ants of the Aphaenogaster testaceopilosa-group (Hymenoptera: Formicidae). Tijdschrift voor Entomologie, 156 (1): 57-93.

BorowIEC L. 2014. Catalogue of ants of Europe, the Mediterranean Basin and adjacent regions (Hymenoptera: Formicidae). Genus (Special issue - Monograph), 25: 1-340.

Borowiec L., Salata S. 2012. Ants of Greece - checklist, comments and new faunistic data (Hymenoptera: Formicidae). Genus, 23 (4): 461-563.

Borowiec L., Salata S. 2013. Ants of Greece - additions and corrections (Hymenoptera: Formicidae). Genus ,24 (3): 335-401.

Borowiec L., SAlata S. 2014a. Redescription of Camponotus nitidescens Forel, 1889, new status and notes on ants from Kefalonia, Greece (Hymenoptera: Formicidae). Genus, 25 (3): 499-517.

Borowiec L., Salata S. 2014b. Review of Mediterranean members of the Aphaenogaster cecconii group (Hymenoptera: Formicidae), with description of four new species. Zootaxa, 3861 (1): $40-60$.

Borowiec L., Salata S. 2017a. New records of ants (Hymenoptera: Formicidae) from Sterea Ellas, Greece. Acta Entomologica Silesiana, 25 (online 020): 1-3.

Borowiec L., Salata S. 2017b. Ants of the Peloponnese, Greece (Hymenoptera: Formicidae). Polish Journal of Entomology, 86 (3): 193-235.

Borowiec L., Salata S. 2018. New records of ants (Hymenoptera: Formicidae) from Epirus, Greece. Acta entomologica silesiana, 26 (online 001): 1-22.

Borowiec L., Galkowski C., Salata S. 2015. What is Tetramorium semilaeve André, 1883? (Hymenoptera, Formicidae). ZooKeys, 512: 39-62.

BračKo G., Kiran K., Karaman C., Salata S., Borowiec L. 2016. Survey of the ants (Hymenoptera: Formicidae) of the Greek Thrace. Biodiversity Data Journal, 4: e7945.

BusChINGER A., EHRHARDT W., FISCHER K., OFER J. 1988. The slave-making ant genus Chalepoxenus (Hymenoptera, Formicidae). I. Review of literature, range, slave species. Zoologische Jahrbücher. Abteilung für Systematik, Ökologie und Geographie der Tiere, 115 (3): 383-401.

CsŐsz S., MARKó B. 2004. Redescription of Tetramorium hungaricum RöSZLER, 1935, a related species of $T$. caespitum (LinnaEus, 1758) (Hymenoptera: Formicidae). Myrmecologische Nachrichten, 6: 49-59.

Csösz S., Heinze J., MiKó I. 2015. Taxonomic Synopsis of the Ponto-Mediterranean Ants of Temnothorax nylanderi Species-Group. PLOS ONE, 10 (11): e0140000.

Csősz S., Salata S., BorowieC L. 2018. Three Turano-European species of the Temnothorax interruptus group (Hymenoptera: Formicidae) demonstrated by quantitative morphology. Myrmecological News, 26: 101-119.

Csősz S., Wagner H.C., Bozsó M., Seifert B., Arthofer W., Schlick-Steiner B.C., Steiner F.M., PÉNZES Z. 2014b. Tetramorium indocile SANTSCHI, 1927 stat. rev. is the proposed scientific name for Tetramorium sp. C sensu SCHLICK-STEINER et al. (2006) based on combined molecular and morphological evidence (Hymenoptera: Formicidae). Zoologischer Anzeiger, 253 (6): 469-481. 
Forel A. 1889. Ameisen aus den Sporaden, den Cykladen und Griechenland, gesammelt 1887 von Herrn von Oertzen. Berliner Entomologische Zeitschrift, 32 [1888]: 255-265.

Galkowski C., Casevitz-Weulersee J., Cagniant H. 2010. Redescription de Solenopsis fugax (LATREILle, 1798) et notes sur les Solenopsis de France (Hymenoptera, Formicidae). Revue Française d'Entomologie, 32 (3): 151-163.

LEGAKIS A. 2011. Annotated list of the ants (Hymenoptera, Formicidae) of Greece. Hellenic Zoological Archives, 7: 1-55.

RAdChenko A.G. 1996. Ants of the genus Plagiolepis MAYR (Hymenoptera, Formicidae) of the central and southern Palearctic. Entomologicheskoe Obozrenie, 75 (1): 178-187.

RAdChEnKo A. 2016. Ants (Hymenoptera, Formicidae) of Ukraine. National Academy of Sciences of Ukraine: I.I. Schmalhausen Institute of Zoology, Kiev.

Rigato F. 2011. Contributions to the taxonomy of West European and North African Stenamma of the westwoodii species-group. (Hymenoptera Formicidae). Memorie della Società Italiana di Scienze Naturali e del Museo Civico di Storia Naturale di Milano, 37: 1-56.

Salata S., Borowiec L. 2015a. Redescription of Crematogaster cypria SANTSCHI, 1930, new status, with description of two new related species from Greece and Turkey (Hymenoptera, Formicidae). ZooKeys, 505: 59-77.

Salata S., Borowiec L. 2015b. Redescription of Temnothorax antigoni (Forel, 1911) and description of its new social parasite Temnothorax curtisetosus sp. n. from Turkey (Hymenoptera, Formicidae). ZooKeys, 523: 129-148.

SAlata S., BorowiEc L. 2015c. A taxonomic revision of the genus Oxyopomyrmex ANDRÉ, 1881 (Hymenoptera: Formicidae). Zootaxa, 4025: 1-66.

Salata S., Borowiec L. 2016. A new species of the Aphaenogaster cecconii group (Hymenoptera: Formicidae) from Rhodes. Zootaxa, 4170 (1): 194-200.

Salata S., Borowiec L. 2017. Species of Tetramorium semilaeve complex from Balkans and Western Turkey, with description of two new species (Hymenoptera: Formicidae: Myrmicinae). Annales Zoologici, 67 (2): 279-313.

Schlick-Steiner B.C., Steiner F.M., Moder K., Seifert B., Sanetra M., Dyreson E., Stauffer C., Christian E. 2006a. A multidisciplinary approach reveals cryptic diversity in Western Palearctic Tetramorium ants (Hymenoptera: Formicidae). Molecular Phylogenetics and Evolution, 40 (1): 259-273.

Schlick-Steiner B.C., Steiner F.M., Konrad H., Marko B., Csősz S., Heller G., Ferencz B., Sipos B., Christian E., Stauffer C. 2006b. More than one species of Messor harvester ants (Hymenoptera: Formicidae) in Central Europe. European Journal of Entomology, 103 (2): 469-476.

SEIFERT B. 2016. Inconvenient hyperdiversity - the traditional concept of "Pheidole pallidula" includes four cryptic species (Hymenoptera: Formicidae). Soil Organisms, 88 (1): 1-17.

Steiner F.M., Csösz S., Marko B., Gamisch A., Rinnhofer L., Folterbauer C., Hammerle S., Stauffer C., Arthofer W., Schlick-Steiner B.C. 2018. Turning one into five: Integrative taxonomy uncovers complex evolution of cryptic species in the harvester ant Messor "structor". Molecular Phylogenetics and Evolution, 127: 387-404. 
Steiner F.M., Seifert B., Moder K., Schlick-Steiner B.C. 2010. A multisource solution for a complex problem in biodiversity research: Description of the cryptic ant species Tetramorium alpestre sp. n. (Hymenoptera: Formicidae). Zoologischer Anzeiger, 249 (3-4): 223-254.

Wagner H.C., Arthofer W., Seifert B., Muster C., Steiner F.M., Schlick-Steiner B.C. 2017. Light at the end of the tunnel: Integrative taxonomy delimits cryptic species in the Tetramorium caespitum complex (Hymenoptera: Formicidae). Myrmecological News, 25: 95-129.

Received: 21 February 2018

Accepted: 23 March 2018 